\title{
DIVINIDAD Y DESASTRES. INTERPRETACIONES, MANIFESTACIONES Y RESPUESTAS
}

\author{
VIRGINIA GARCÍA ACOSTA \\ CIESAS-México \\ vgarciaa@ciesas.edu.mx
}

\begin{abstract}
«La naturaleza es un instrumento y una herramienta de Dios, es por tanto una causa secundaria; Dios es la causa prima. La naturaleza es la sierva de Dios» Johann Neubeck, Obispo de Viena, 1590. ${ }^{1}$
\end{abstract}

\section{Resumen}

Atribuir a un origen supranatural o divino la presencia de amenazas naturales o biológicas, e incluso de desastres, ha constituido una constante a lo largo de la historia de la humanidad. No obstante, las formas sociales y culturales, así como las manifestaciones y respuestas en diferentes geografias y momentos históricos, dan cuenta de las múltiples y complejas maneras en que el hombre, a traves de la cultura, perfila su interpretación de y su relación con la naturaleza y con la divinidad.

Este ensayo presenta una selección de ejemplos ilustrativos al respecto, provenientes de fuentes primarias trabajadas por investigadores especialistas en el estudio histórico y social de los desastres. Se centra espacial y temporalmente en los confines de la Monarquía Hispánica, rebasándolos cuando resulta necesario llevar a cabo comparaciones y contrastes.

Palabras clave: Catástrofes naturales, Católicos vs protestantes, Desastres históricos, Hispanoamérica, Ilustración, Religión y ciencia, Religiosidad popular, Virgen María-advocaciones.

1. «Nature is an instrument and tool of God, and is therefore a secondary cause; God is causa prima. Nature is the servant of God». Extracto del sermón predicado por el Obispo Católico de Viena, Johann Neubeck, con motivo de un temblor que estremeció a la ciudad el 25 de septiembre de 1590, período en que dominaba la Casa de Austria, parte de la Monarquía Hispánica. Citado en Fulton, 2012: 55. 


\begin{abstract}
Divinity and Disasters. Interpretations, demonstrations and answers

To attribute to a supranatural or divine origin the presence of threats natural or biological hazards, and even disasters, has constant throughout the history of humanity. However, social and cultural forms, as well as manifestations and responses in different geographies and historical moments, account for the multiple and complex ways in which man, through culture, its interpretation of and its relation to nature and to the divinity.

This paper presents a selection of illustrative examples, from primary sources worked by researchers specialists in the historical and social study of disasters. It focuses spatially and temporally on the confines of the Hispanic Monarchy, passing them when it is necessary to carry out comparisons and contrasts.
\end{abstract}

Keywords: Natural disasters, Catholic vs. Protestants, Historical disasters, Latin America, Illustration and Painting, Religion and Science, Popular Religiosity, Virgin Mary-invocations.

\title{
Introducción
}

Atribuir a un origen sobrehumano, supranatural o divino la presencia de fenómenos naturales, de amenazas biológicas o, incluso, de desastres asociados con ellas, ha constituido una constante a lo largo de la historia de la humanidad.

Sin embargo, las formas sociales y culturales que esa atribución ha presentado, así como la plasticidad de las manifestaciones y respuestas que a diferentes escalas hemos identificado en geografias y momentos históricos variados, dan cuenta precisamente de las múltiples y complejas maneras en que el hombre, a traves de la cultura, perfila su interpretación de y su relación con la naturaleza y con la divinidad.

La información para este ensayo proviene de fuentes primarias, buena parte obtenida a partir de investigaciones de especialistas en el estudio histórico de los desastres, del clima, de la relación hombre-naturaleza en y desde diferentes partes del planeta. He llevado a cabo una selección de los ejemplos que me han parecido ilustrativos e, incluso, emblemáticos. Venturosamente la bibliografía ha resultado mucho más rica de lo que esperé antes de trabajar el 
tema de este texto, y constituye un subproducto que espero sirva para nuevas incursiones en el mismo.

El ensayo está centrado en el territorio que abarcaba la Monarquía Hispánica, por lo que cubre el periodo que corre del siglo XVI a inicios del XIX, sin necesariamente seguir un orden cronológico en el relato. En ocasiones, para llevar a cabo comparaciones y contrastes, haré referencia a períodos previos o posteriores, así como a espacios que salen del ámbito estrictamente hispánico. ${ }^{2}$

\section{Interpretaciones sobre el origen}

Alfredo López Austin, nos ofrece análisis profundos del concepto de cosmovisión. Invita a concebir la realidad como «un vínculo entre lo que llamamos mundo objetivo y mundo subjetivo [...] somos naturales y sociales, y la calidad social determina, a causa de la diversidad cultural, notables diferencias en la percepción del mundo». ${ }^{3}$ Derivada de ello, la cosmovisión debe entenderse como un hecho histórico y complejo, e inmerso en procesos de larga duración: un sistema de sistemas. ${ }^{4}$ Si bien por lo general el término se ha reservado al pensamiento e interpretación que de su realidad han hecho o hacen las así denominadas «sociedades tradicionales», considero que para el caso que nos ocupa resulta muy útil para revisar diversas interpretaciones que sobre el origen de los fenómenos naturales, de las amenazas biológicas e incluso de los desastres asociados a ellas se han desarrollado en el acontecer histórico. Lo que podríamos denominar una forma de «cosmovisión de lo desastroso».

\section{Castigo divino}

La interpretación de la presencia de fenómenos naturales devenidos amenazas, así como de la ocurrencia de desastres como manifestación de la ira divina, fue la dominante durante muchos siglos tanto en Europa, como en los países colonizados por los europeos. Castigo divino asociado con el pecado, que asociaba al miedo y la contricción como respuestas de la sociedad arrepentida.

2. Las Figuras 1, 2 y 3 muestran los países actuales sobre los cuales se presentan ejemplos en este ensayo. Aparecen al final del mismo.

3. LÓPEZ AUSTIN, 1996:471.

4. LÓPEZ AUSTIN, 1996: 472. 
Una de las mejores fuentes para el estudio de esta interpretación son precisamente los sermones que predicaban los sacerdotes, católicos o protestantes, después de ocurrido un desastre, teniendo siempre presente el recuerdo de la destrucción de Sodoma y Gomorra o el espectro del juicio final.

Predicadores protestantes, como John Shower, identificaron los temblores de Jamaica de 1692, así como los de Sicilia del año siguiente, como un signo de descontento del disgusto de Dios que, con él, exhortaba a los ingleses a arrepentirse. ${ }^{5}$ Thomas Sherlock, quien fuera arzobispo de Londres por más de tres décadas, en ocasión de la ocurrencia de temblores en la primera mitad del siglo XVIII, hacía referencia a la maldad y corrupción reinantes en la ciudad, manifiestas en publicaciones antirreligiosas, el papismo, la homosexualidad y las diversiones lascivas, que habían desatado la más terrible ira divina. ${ }^{6}$

El castigo divino podía tener un referente específico, como en el caso de 1607 en la ciudad de Santiago de los Caballeros de Guatemala, ocasión en que los religiosos recordaban a sus feligreses que lo merecían y que, aunque con retraso de 60 años, se había manifestado con el temblor ocurrido por haber asesinado a su obispo en $1546 .^{7}$

Cometer pecados capitales era una falta grave, un error capital como su nombre lo indica, que merecía un escarmiento y un severo castigo. La avaricia fue la responsable de aquel memorable temblor de 1746 en Lima y Callao, uno de los más estudiados en la América Hispánica durante esa centuria, en que se hablaba de que la enorme riqueza de la Iglesia, y lo licencioso que se habían vuelto los sacerdotes, había sido el origen del mismo; por ello en las procesiones se rezaba: «Lima, Lima, tus pecados son tu ruina». ${ }^{8}$ La soberbia, por su parte, fue utilizada para explicar el otro memorable temblor dieciochesco, ocurrido el día de todos los santos de 1755 en Lisboa, ocasión que aprovechó el Caballero de Cogolin, Joseph de Cuers, poeta francés reconocido y miembro de las Academias de Berlín y de Nancy, para insistir en que fue

\footnotetext{
5. TOBRINER, 1999: 50.

6. Citado en Johns, 1999: XXIII, n. 5

7. MUSSET, 1996:55; 2011.

8. PÉrez Mallaina, 2001; Walker, 1999: 119
} 
provocado por el enojo divino al haberse convertido los lisboetas en unos personajes excesivamente orgullosos. ${ }^{9}$

Pero el castigo divino podía, también, ser diferencial. En la región de Ambato y Patate, hoy Ecuador, con relación al temblor que asoló la región en 1698, un documento señalaba que arruinó a

los habitantes de Patate, insensibles pecadores castigados por la cólera divina [pues] fuera del pueblo de Patate, otro ninguno de indios padeció daño alguno, con que se deja entender que Dios quiso castigar tan severamente a los españoles, quizá por los agravios y extorsiones que ellos hacen a los pobres indios. ${ }^{10}$

Las prácticas consideradas como idólatras y paganas que se conservaban en las colonias americanas, aún después de haber pasado varios siglos de la conquista de los territorios, seguían siendo consideradas punibles. El 21 de octubre de 1766, el día que al decir de Rogelio Altez «tembló en toda la fachada suramericana [dando lugar al] terremoto con más alcance territorial en la historia documentada del continente suramericano», se ha vinculado con una «imaginada danza indígena que celebraba el fin del mundo»: ¿castigo divino? Para evitar que se repitiera, al año de ese sismo se conmemoró en Ocumare de la Costa, ocasión en la que se congregaron en una «suntuosa función» más de 2 mil personas. «Hubo rezos, cantos, miserere, músicos y peones [...] La gente se atropellaba en los confesionarios para purificar sus consciencias, por lo que el sacerdote del lugar abría el confesionario desde las tres de la madrugada hasta las doce de la noche». ${ }^{11}$

Charles Walker, en su comparación de tres temblores dieciochescos: Lima 1746, Quito 1783 y Arequipa 1797, relata que en el primero de ellos el Virrey Manso de Velasco, reconociendo el origen divino del desastre, tomó medidas enérgicas para prevenir el delito, restablecer el orden y reconstruir la ciudad, entre ellas ordenó que las mujeres, en cualquier estado, clase o condición,

9. TOBRINER, 1999: 50. Más de dos siglos después, una explicación similar se dio en algunos ámbitos a la ocurrencia del tsunami del 11 de marzo de 2011: fue un castigo del cielo al haberse convertido los japoneses en codiciosos y egoístas: JANKU, SCHENK y MAUELSHAGEN, 2012: 8. Sobre el sismo de Lisboa ver, entre otros, KENDRICK, 1955; SOUSA, 1984; Araujo, 1995 y 2005; AlBEROla, 2005.

10. MUSSET, 1996: 58-59.

11. Altez, 2016: 299, 303, 305, 414. 
debían usar ropa que cubriera sus pies y sus muñecas, incluso al estar montando una mula; sus sirvientas debían hacer lo mismo. ${ }^{12}$

Si bien en la mayoría de los casos que hemos localizado, el mensaje de sentencia divina se relaciona con la ocurrencia de sismos, también aparece en casos de epidemias, incluso como avisos premonitorios. El mexicano Cayetano Cabrera Quintero, quien fuera presbítero del Arzobispado de México, fue el autor de un valioso documento titulado Escudo de armas, que ha sido una de las bases para el estudio de los efectos de la epidemia de matlazahuatl (tifus exantemático), que asoló el virreinato de la Nueva España, y particularmente la ciudad de México, durante los aciagos años de 1736 a 1739. Reconocido incluso en su momento como especialista en la materia, en 1736 fue invitado a dictar un discurso en la Academia de Medicina en la que, además de hablar sobre la epidemia que estaba en ese momento devastando particularmente a la población más vulnerable, consideraba que la causa de la enfermedad era producto de un castigo celestial y que ciertos fenómenos naturales, presentes con anterioridad, como temblores y lluvias abundantes, acompañados de eclipses solares, la habían presagiado. ${ }^{13}$

La mezcla entre la gran diversidad de concepciones la encontramos en descripciones más tempranas que las anteriores, como aquéllas legadas por el cronista indígena andino Felipe Guamán Poma de Ayala, mejor conocido como Guamán Poma quien, después de recorrer el territorio que entonces constituía el Virreinato del Perú hacia las últimas décadas del siglo XVI, escribió El primer nueva corónica y buen gobierno entre 1612 y 1613. Consideraba tanto las epidemias como las erupciones volcánicas como castigo divino, y como tal lo expresó al referirse al ocurrido en Arequipa diciendo que «fue castigado por Dios como reventó el volcán y salió y se asomó los malos espíritus y salió una llamarada y humo de ceniza y arena y cubrió toda la ciudad y su comarca donde se murieron mucha gente y se perdió [sic] todas las viñas y ajiales y sementeras». ${ }^{14}$ Seguramente se refiere al temblor que los especialistas en sismología histórica del Perú han registrado para el 22 de enero de 1582, que «dejó en ruinas a la ciudad de Arequipa. Cayeron alrededor de 300

12. WALKER, 1999: 121.

13. Molina, 2001a: 55.

14. Citado por CAMINo, 1996: 146.

Revista de Historia Moderna, n. ${ }^{\circ} 35$ (2017) (pp. 46-82) | ISSN-e: 1989-9823 | ISSN: 0212-5862 
casas y perecieron más de 35 personas, muchas de ellas sepultadas entre los escombros.» ${ }^{15}$

\section{Origen divino pero no castigo divino}

El castigo, manifiesta en el desastre, como producto de la ira divina es característico de la tradición judeo-cristiana. No se perciben como castigos, aunque si provenientes de manifestaciónes divinas, en otras tradiciones e interpretaciones que hemos identificado. Al respecto ofrecemos dos ejemplos contrastantes procedentes de tiempos y espacios distintos y distantes: Mesoamérica, en la época prehispánica, y el noreste de la India en pleno siglo XVIII.

La concepción cíclica del tiempo, vinculada con el calendario, fue una constante en Mesoamérica. ${ }^{16}$ El interés de los pueblos mesoamericanos por dejar constancia de la presencia de fenómenos naturales de origen geológico o meteorológico, se deriva de dicha concepción ciclíca y apocalíptica. Los Anales de Cuauhtitlán relatan las cinco eras o edades por las que ha pasado el universo, en ciclos de 52 años cada uno, representados por diversos soles creados por los Dioses. La quinta era, en la que aún nos encontramos y que se denomina por ello era del quinto sol, se identifica con los movimientos. De acuerdo a la cosmogonía nahua, el fin de ese quinto sol ocurrirá a causa de terremotos. Esa es una de las razones por las cuales en sus códices y anales, asentados utilizando la escritura prictográfica, el registro de los sismos ocurridos se hacía con todo cuidado y regularidad. ${ }^{17}$ Pero también otras amenazas naturales y biológicas eran registradas con cuidado. Sequías, inundaciones, nevadas, granizadas y huracanes, así como plagas y epidemias ocurridas antes de la llegada de los españoles, aparecen descritas en códices y anales, así como

15. GIESECKE y SILGADO, 1981: 13.

16. Los límites geográficos para Mesoamérica en el momento de la conquista, según el clásico trabajo de Paul Kirchhoff son: al norte «más o menos del río Panúco al [río] Sinaloa pasando por el [río] Lerma», al sur «más o menos, desde la desembocadura del río Motagua hasta el Golfo de Nicoya, pasando por el lago de Nicaragua». KIRCHHOFF, 1967: 7.

17. ANALES DE CUAUHTITLÁN, 1885: 9-10. Los Anales de Cuauhtitlán constituyen la primera de las tres partes que conforman el Códice Chimalpopoca. 
en los escritos legados por los cronistas-soldados y cronistas-misioneros de los primeros siglos de la conquista. ${ }^{18}$

El segundo ejemplo corresponde a aquélla que David Arnold caracterizó como la devastadora hambruna bengalí de 1770, y que identificó como una de las grandes catástrofes del siglo XVIII. Empezó con una gran sequía, seguida de escasez y carestía de granos que provocaron muerte y migración masivas. Más de la mitad de la población del área afectada murió. Diversas menciones en la documentación revisada por Arnold dan cuenta de que la invocación a la divinidad y al cielo indican una convicción profunda de que el destino está determinado por voluntad divina, de que Dios había de bendecir a sus fieles y enviar la ayuda necesaria para salir adelante, que el remedio se encontraría en la misericordia de Dios, pero nunca en referencia a un castigo al que podrían haber sido merecedores los humanos por su impío comportamiento. ${ }^{19}$ Pero la hambruna no vino sola, se incrementó la crisis a causa de una epidemia de viruela que atacó a la población de todas las edades. Ésta sí fue identificada directamente como una manifestación de la Diosa hindú Sitala, que no había sido honrada y propiciada de manera correcta a través de canciones y oraciones adecuadas y que, en este caso, había hecho sentir su ardiente cólera dejando marcas desfigurantes e imborrables en la piel de los individuos cuyos cuerpos había decidido poseer. ${ }^{20}$

\section{Respuestas y manifestaciones}

Las diversas respuestas y manifestaciones una vez ocurrido el desastre, respondían a las diferentes concepciones atribuidas a su origen, aunque en general existía la convicción de que si el desastre provenía de un designio divino o sobrenatural, de la misma fuente debería derivarse su solución. Pero aquí, de nuevo, las mayores diferencias las encontramos entre las sociedades con influencia judeo-cristiana y aquéllas que, como la mesoamericana, tenían (y

18. Provenientes de los Códices Aubin, en Cruz, Telleriano-Remensis, así como de los Anales de Tlaxcala y Anales de Tula, entre otros, estos registros se encuentran recopilados en García Acosta, Pérez Zevallos y Molina del Villar, 2003.

19. ARNOLD, 1999: 81-95.

20. ARNOLD, 1999: 103-104. 
en algunos casos en comunidades indígenas aún mantienen) una cosmovisión muy distinta.

Dentro de la cosmovisión mesoamericana, la religión se presenta como un politeísmo prolijo en el cual, si bien los seres sobrenaturales tenían enormes poderes y facultades para producir transformaciones en el cosmos, los hombres en la tierra mantenían una relación y un trato constante e intenso con ellos hasta el punto de poder influir en ellos. Así, lo intentaban «a través del ruego, el convencimiento, la promesa, el compromiso, la amenaza, en fin, por medios semejantes a los que usaba[n] normalmente para afectar a sus semejantes». ${ }^{21}$ Así, en el Códice Vaticano A se menciona que en Tula, alrededor del siglo XII, gracias a que Quetzalcóatl, la serptiente emplumada que representaba una de sus principales deidades, hizo ofrendas a los Dioses para que la tierra diera «frutos con alegría [...] pronto vino tanta abundancia que aquella tierra estéril produjo muchos». ${ }^{22}$

Por lo que toca a los ritos preventivos o propiciatorios, era el Sagrado Recinto de Tenochtitlan, ubicado al centro de la gran ciudad nahua, el lugar donde se desarrollaban las imponentes ceremonias que los incluían. Eran dedicadas a la búsqueda de alivio de las grandes desgracias infligidas por los Dioses para castigar a los seres humanos: desastres agrícolas, hambrunas, epidemias, plagas. ${ }^{23}$

Con la imposición del cristianismo, a partir de la conquista de México consumada en 1521, la institucionalidad político-religiosa de los indígenas mesoamericanos, así como esta cosmovisión, sería destruida. Lo anterior, en el caso de los mayas peninsulares que habían desarrollado diversas maneras para relacionarse con sus Dioses, particularmente ritos preventivos que, gracias a su conocimiento de la cíclica ciclónica sabían de su inminente presencia anual, fue severamente sancionada al grado de que, como señala Isabel

21. LÓPEZ AUSTIN, 1996: 475, 478.

22. GARCía Acosta, PÉReZ y Molina, 2003: 71. El códice mencionado, que actualmente se conserva en la Biblioteca Apostólica Vaticana, contiene información sobre tradiciones cosmológicas y mitológicas, al igual que calendarios y anales indígenas de 1195 hasta 1562.

23. LÓPEZ AUSTIN y LÓPEZ LUJÁN, 2016: 10. 
Campos, «la sociedad maya se volvió incapaz de generar respuestas ideológicas ante huracanes», como si lo había hecho en la época prehispánica. ${ }^{24}$

Las ceremonias mesoamericanas tenían, en el fondo, el mismo propósito que las manifestaciones y prácticas que encontramos abundantemente documentadas para el periodo imperial, aunque no ceñidas exclusivamente a las colonias. Reconociendo el origen divino o sobrenatural de la presencia de las amenazas naturales o biológicas, lo que se pretendía era agradar, complacer, venerar, honrar a sus Dioses para evitar o al menos disminuir la recurrencia observada de desastres. Con dos diferencias sustanciales: en las sociedades mesoamericanas por un lado no se les identificaba como castigos divinos y, por otro, no existía una concepción fatalista dado el convencimiento de poder dialogar e influir en las decisiones adoptadas por sus deidades. ${ }^{25}$

Aquellos que podríamos denominar como rituales propiciatorios, relacionados con amenazas naturales y desastres en el área andina, aparecen descritos también por el ya referido cronista indígena Guamán Poma. Así, «durante la época de granizo o helada, así como cuando 'no viene agua del cielo', por mandato del Inca, la gente debía pintarse la cara de negro y andar por los cerros implorando a Pacha Camac», el creador del universo, recitando plegarias. De la misma manera en el mes de octubre, y con la finalidad de propiciar las lluvias, «se sacrificaban cien carneros a las huacas», una divinidad local. En noviembre, mes regularmente seco en la región, «se sacaba a pasear, de casa en casa y en andas, a las momias de los antepasados; se les daba de comer y de beber y se les adornaba». Lupe Camino nos explica que «la ausencia de lluvias guarda relación con las defunciones; esto se manifiesta en estas plegarias por la insistencia en el 'luto' y por la auto calificación de los suplicantes como personas con 'caras de muerto'». ${ }^{26}$

Avisos divinos o sobre naturales, que permitieran llevar a cabo acciones y prácticas propiciatorias o preventivas, enviadas por vírgenes o santos y, en ocasiones incluso en la actualidad, transmitidas por shamanes, graniceros o los «profetas de la lluvia» (profetas da chuva) de Brasil, aparecen con

24. CAMPOS, 2008: 165.

25. CAMPOS, 2008: 176.

26. CAMINo, 1996: 140, 141, 143. 
frecuencia en la documentación. ${ }^{27}$ Con relación al temblor de 1687, Susana Aldana, a partir de la documentación por ella analizada, concluye lo siguiente

Desesperados decían que debían haberse dado cuenta de los avisos del castigo. ¿No había habido numerosas incursiones de piratas en las costas del Virreinato, amenazando la tranquilidad del reino en ese mismo año? Más aún, ¿no había sudado y llorado misteriosamente varias veces una imagen de la virgen a partir de julio? Se trató en realidad de un lapso crítico, aunque no fue tan sólo de fenómenos naturales. ${ }^{28}$

Una década más tarde, poco antes del terremoto que en 1698 asoló la región ecuatoriana de Ambato y Patate antes mencionado, «una imagen de la Virgen había llorado lágrimas de sangre con el fin de advertir a los fieles la inminencia del desastre. Esta señal del cielo desafortunadamente no fue comprendida por los habitantes de Patate,» nos dice Alain Musset. ${ }^{29}$

Tres siglos después encontramos escenarios similares en México y Filipinas. Días antes del 28 de marzo de 1982, fecha en que hizo erupción el volcán Chichonal en Chiapas, México afectando a más de 20 mil indígenas zoques, se presentaron varios augurios: el canto de los pájaros ori, el paso de aves negras con pico blanco y, sobre todo, la presencia nocturna de la piowacwe, que en lengua zoque significa «la vieja», anciana que habita dentro del volcán y sale para anunciar su ineludible y próxima explosión. ${ }^{30}$ Por su parte en Filipinas, dos noches antes de la erupción del Pinatubo en 1991, ésta había sido anunciada por un visionario de Botolan, ataviado con una túnica blanca, a la vez que un médium en trance transmitió un mensaje de la propia Virgen María dirigido al alcalde Gordon de Olongapo, indicando que la ciudad se salvaría si se organizaba una procesión para rogar por la divina intervención. ${ }^{31}$ Como bien señala Armando Alberola, magia, superstición y religiosidad bien podían llegar a confundirse en las innumerables y diversas manifestaciones resultantes de tales avisos, incluyendo los conjuros y exorcismos que, aunque criticados y prohibidos por considerarlos «propios de la superstición y ajenos

27. Cfr. Albores y Broda, 2003 y JuÁrez BeCerril, 2015 para México, así como el estimulante Profetas da chuva (MARTINS, 2006).

28. AldANA, 1996: 172.

29. MUSSET, 1996: 58; 2011.

30. BÁEZ-JORGE, RIVERA y ARRIETA, 1985: 70-72.

31. BANKOFF, 2003: 172. 
al ritual romano», se practicaban particularmente en el caso de enfermedades, epidemias o plagas. $^{32}$

\section{Procesiones y rogativas}

En los confines del Imperio Español, las manifestaciones y prácticas religiosas propiciatorias o preventivas, pero sobre todo las organizadas una vez ocurrido algún desastre asociado con amenazas naturales de origen geológico (sismos, erupciones volcánicas), hidrometeorológico (sequías, heladas, granizadas, inundaciones) o biológico (epidemias), incluían procesiones, rogativas públicas, fiestas a santos, letanías, misas, novenarios, plegarias, canto del Te Deum, peregrinaciones. En su espléndido trabajo Francois Walter identifica estas manifestaciones religiosas y prácticas devocionales como «un sistema coherente de gestión del trauma». ${ }^{33}$ Entre ellas, las más y mejor documentadas tanto en material de archivo como en fuentes secundarias son las procesiones y rogativas.

La primera procesión de la que tenemos registro en la Nueva España se organizó a causa de una epidemia en 1545, para la cual se mandó que «todos los oficiales, mercaderes y otras personas de esta ciudad [de México] los miércoles de cada semana cierren las puertas de sus tiendas y de sus oficos y no hagan nada y vayan acompañando la dicha procesión donde quiera que fuere». La siguiente, una década después, tuvo como origen «la falta de agua en las sementeras y porque mañana martes ha de ir la procesión a Santa Ana y después de mañana miércoles a San Juan [...] mandaron se pregone que todos vayan $[. .$.$] y que no se abran las tiendas ni los oficiales de los oficios$ mecánicos trabajen». ${ }^{34}$

La mayoría de ellas tenían las características y componentes que aparecen en el informe que el Virrey de la Nueva España, Juan Antonio de Vizarrón y Eguiarreta, rindió al Consejo de Indias durante la epidemia de matlazahuatl

32. Alberola, 2003: 404; Alberola 2016; Alberola, Bueno y García, 2016.

33. WALTER, 2008:41. La enorme cantidad de ejemplos que, en diferentes partes del mundo, ofrece Walter para sustentar sus afirmaciones resulta sorprendente. DOUGLAS, 1992.

34. Ambas citas proceden del ramo Actas de Cabildo Impresas (ACI) del Archivo Histórico de la Ciudad de México (AHCM), en: García ACOSTA, PÉrez y Molina, 2003: 101 y 112 , respectivamente. 
de 1736 diciendo que «se ha solicitado [... el el socorro espiritual de las divinas con plegarias, novenas, rogativas a Dios, a su santísima Madre y santos especiales, abogados de esta ciudad y pueblo, procurando aplacar su justísima ira con las procesiones y públicas penitencias». ${ }^{35}$ A primera vista podría parecer que las procesiones, rogativas y similares eran idénticas. Sin embargo, una mirada atenta a las mismas permite identificar diferencias, especificidades y cambios a lo largo del tiempo y hasta mediados del siglo XIX, cuando tal como lo describe América Molina en su detallado estudio de caso sobre el sismo del 19 de junio de 1858 en la ciudad de México, la Iglesia manifestó ya «un comportamiento tímido» en las expresiones y prácticas religiosas posteriores al mismo, pues por ejemplo sobre «las procesiones religiosas que eran tan frecuentes y concurridas en épocas previas y a través de las cuales podíamos apreciar el poder espiritual ejercido por la Iglesia, no se encontraron evidencias directas que permitan evaluar su importancia». ${ }^{36}$

Eran organizadas por el gobierno de turno y por la Iglesia, teniendo la última palabra en ello el Virrey. Dos textos de fines del siglo XVI dan cuenta de lo anterior:

En la sesión de 30 de junio [1580], reunidos en cabildo, los señores corregidor, alcaldes y regidores dijeron que: este presente año por tardarse las aguas tanto, no se han podido sembrar y hacer sementeras y han redundado muchos [sic] enfermedades y daño a la república y acordaron solicitar al señor arzobispo por parte de esta ciudad [de México] sea servido mandar hacer plegarias, procesiones y rogativas a Nuestro Señor para que sea servido aplacar su ira y usando de su divina misericordia haga bien y merced a esta ciudad y su república de les dar ayuda [con] buenos temporales. ${ }^{37}$

En la sesión de cabildo del 10 de junio [1588] se trató que sería bien hacer plegarias y procesiones por el agua y por las enfermedades que hay en la tierra y se comisionó a Diego de Velazco alguacil mayor, para que hable con el virrey al respecto. ${ }^{38}$

35. Este informe, al igual que buena parte del que ha utilizado América Molina para su estudio del matlazahuatl, fue localizado en el Archivo General de Indias por ella misma: MOLINA, 2001a: 152.

36. MOLINA, 2001b: 252.

37. ACI, AHCM, en: García ACOSTA, PÉREZ y Molina, 2003: 127

38. Proveniente de ACI, AHCM, en: GARCía ACOSTA, PÉrez y Molina, 2003: 131. 
A pesar del peligro de contagio, razón por la cual en otros espacios se limitó su realización para evitar potenciar la expansión de la enfermedad, como fue el caso de la terrible peste que asoló el norte de Italia en 1630, ${ }^{39}$ estos actos que reunían a cientos y en ocasiones a miles de personas, se llevaban a cabo en espacios públicos como calles, plazas y templos. Su organización, en la Nueva España, estaba a cargo de los denominados «diputados de fiestas», elegidos cada año por el ayuntamiento de entre los regidores de justicia sin cargo. Iban encabezadas por el virrey, seguido de la clerecía, los miembros del Ayuntamiento y de la Real Audiencia, enseguida las cofradías y los gremios en orden de importancia, la guardia real y, al final, el pueblo. Generalmente había puestos de dulces, comida y, en ocasiones, fuegos artificiales y máscaras. ${ }^{40}$

Sobre rogativas relacionadas en específico con amenazas hidrometeorológicas que provocaban desastres agrícolas de diversa magnitud, encontramos cerca de 40 registros a lo largo de la época colonial novohispana, referidas en su mayoría a la ciudad de México, pero también a Chiapas, Guanajuato, Jalisco, Michoacán, Puebla, Querétaro, San Luis Potosí, Yucatán y Zacatecas. ${ }^{41}$

El origen de las rogativas data de los primeros siglos de la cristiandad. «Se atribuye su instauración a San Mamerto, obispo de Viena, entre los años 458-474, tras sufrir la ciudad un terremoto, seguido de un virulento incendio, y el ataque de feroces lobos que diezmaron la población.» ${ }^{42}$ Con el paso del tiempo fueron alcanzando una importancia y esplendor cada vez mayor, difundiéndose por todo el orbe cristiano.

Las rogativas en España, que han sido profusamente estudiadas por Alberola, ${ }^{43}$ constituían igualmente un recurso de la religiosidad popular. Se

39. En diversos bandos y edictos promulgados se hacía mención a esta amenaza. MoLINA, 2001a: 152-153.

40. La gran mayoría de la información aquí presentada procede de MolinA, 1996, GARCíA TORRES, 2016 y GARCÍA ACOSTA, 2001.

41. García AcOSTA, PÉRZ y Molina, 2003. Al parecer García Torres, en la investigación realizada durante 2016 en archivos mexicanos, centrada en el siglo XVIII, ha encontrado nueva información que esperamos pronto conocer, procedente sobre todo de las actas del Cabildo Eclesiástico de la Catedral: GARCía TORRES, 2016.

42. Alberola, 2003: 399.

43. Existe una gran cantidad de trabajos al respecto desarrollados por Alberola y su grupo de investigación en la Universidad de Alicante. Entre ellos podemos mencionar: Alberola, 2003 y 2004 y García Torres, 2013. 
caracterizaban por ser pro-pluvia, en el caso de sequías y pro-serenitatem, en el de inundaciones. En el caso de las primeras, que son la mayoría sobre todo para el caso de Valencia, se han constituido en un indicador climático a partir del análisis cuantitativo y cualitativo de la información localizada particularmente en documentación proveniente de los cabildos civil y eclesiástico. Con base en ella es posible distinguir tres niveles de sequía: nivel 1, que corresponde a una sequía leve y cuyo acto religioso se concentraba en llevar a cabo ruegos privados; el nivel 2, considerado moderado, conllevaba rogativas públicas y colectas; el nivel más elevado, calificado como grave y grado 3, ya incluía procesiones, traslados y otras ceremonias.

Tanto las procesiones como las rogativas se caracterizaban por constar de los siguientes elementos, que Molina ha identificado con claridad: calendario, reglamentación, mitos, rituales, espacio y adorno.. ${ }^{44}$ Aquéllas organizadas cuando la magnitud del desastre lo requería, eran las denominadas procesiones de penitencia y las procesiones de sangre que, además de los elementos mencionados, incluían castigos corporales como flagelos o llevar la cruz a cuestas emulando los pasos de Cristo, en actos de penitencia y contricción para amainar la ira divina. Durante la erupción del volcán de Fuego en Antigua Guatemala en agosto de 1717, los habitantes de esa ciudad «llevaron a cabo procesiones de rogativas y penitencias en las que los miembros del clero, incluyendo el obispo, llegaron a salir 'con la cabeza regada de ceniza, corona de espinas, soga a la garganta y cargando cruz'. ${ }^{45}$

Relatos sobre procesiones abundan en la documentación recopilada por los estudiosos de la historia de los desastres. Pidiendo el cese de las epidemias, e incluyendo el traslado de la Virgen de los Remedios o de la de Guadalupe en la ciudad de México. Rogando por el cese de la sequía en Oaxaca con traslado de la Virgen de la Soledad o llevando en andas la figura del Cristo Crucificado. Cargando a la Virgen de la Merced y a la del Rosario contra temblores en Caracas. Con la imagen de San Nicolas Tolentino para que cesen las inundaciones en Michoacán. Transportando a la Virgen María reintepretada con la Pachamama o madre tierra, divinidad tectónica nativa, después de la erupción volcánica en Arequipa.

44. MOLina, 1996: 97.

45. Peraldo y Mora, 2008: 133.

Revista de Historia Moderna, n. ${ }^{\circ} 35$ (2017) (pp. 46-82) | ISSN-e: 1989-9823 | ISSN: 0212-5862 
El estudio de Giovanni Peraldo y Mauricio Mora, a diferencia de otros, ofrece un cronograma diario de las diversas actividades y prácticas religiosas llevadas a cabo «para aplacar la erupción del volcán Irazú en 1723» en Cartago, Costa Rica desde el día en que ocurrió, el 16 de febrero a las 15 horas, y hasta las 3 de la mañana del 5 de marzo siguiente. ${ }^{46}$ Incluyen en él la imagen venerada, paseada o trasladada y las actividades eclesiásticas celebradas. Entre las primeras se encuentra una gran variedad de devociones, que aparecen una, dos o hasta seis veces, como es el caso de Nuestra Señora de Ujarrás, ${ }^{47}$ acompañada de Nuestras Señoras del Rosario, del Carmen y del Trono, Santos como Pedro, Nicolás de Bari o Gregorio Obispo, la Reina de los Ángeles, y Jesucristo en la figura de Niño Jesús, Cristo de la Victoria, Divino Señor Sacramentado y Jesús Nazareno. Por su parte, las actividades llevadas a cabo día con día incluían al menos dos de las siguientes: rosario, letanía, velación, procesión, procesión de rogativa, sermón, misas cantadas, en ocasiones con acompañamiento de guardia real. La última de ellas, efectuada el 5 de marzo fue «acompañada por 100 soldados de la guardia real, 'continuamente fueron haciendo fuego' hasta la población de Ujarrás.» La documentación revisada permite afirmar a estos estudiosos de la geología centroamericana y sus manifestaciones que la «profunda fe de la población en las actividades religiosas los llevó a considerar que cada vez que celebraban los oficios religiosos, la actividad del volcán disminuía». ${ }^{48}$

Un par de celebraciones poco comunes proceden de Suiza y de Nueva España. El primero se llevó a cabo en uno de los cantones católicos de Suiza, a raíz del temblor del 18 de septiembre de 1601: la «Devoción de las Cuarenta Horas». Calificado como el acontecimiento más fuerte conocido en la Suiza central del post-milenio, su realización y la participación obligatoria fue ordenada por el gobierno de la ciudad de Lucerna. Se trató de una ceremonia en

46. Para el caso de la villa de Cocentaina en Valencia, con motivo de la plaga de langosta que se presentó en 1756, en el mes de julio, y como parte del «contexto de temeroso fervor, fueron suprimidas las diversiones públicas y sacadas en procesión casi a diario la práctica totalidad de las imágenes de vírgenes y santos, hasta culminar con un gran desfile penitencial que reunió a todo el conjunto el día diecinueve de julio.» AlBEROLA, 2003: 400.

47. Advocación de la Inmaculada Concepción, patrona de la villa del mismo nombre hoy sitio histórico, ubicado en la provincia de Cartago.

48. Peraldo y Mora, 2008: 135. 
tándem, que consistía en que se llevaba a cabo una hora de oración en una iglesia que, al terminar, iniciaría en la siguiente, y así sucesivamente por todas las iglesias lucernenses hasta el final de las cuarenta horas definidas. Era ésta una estimación de la longitud del tiempo que Cristo pasó en la tumba antes de resucitar. Para Elaine Fulton, la Devoción de las Cuarenta horas constituye otra forma de respuesta confesional, dando cuenta de una clarísima respuesta católica al desastre en una ciudad cuya identidad económica, política y religiosa dependía de una fuerte alianza con Roma. ${ }^{49}$

El segundo caso poco común proviene del real de minas de Guanajuato y sus alrededores, en cuyo caso se celebró en 1790 un «noviembrenario de rogación» que, al parecer, alcanzó excelentes resultados:

Hallándose este real y su jurisdicción en la mayor consternación a causa de la seca que ha experimentado por 22 meses continuos, el reverendo padre Joseph Delgado de la orden de la merced, cura sustituto del mismo, asociado del teniente don Joseph Joaquín Franco, promovió entre sus feligreses la celebración de un noviembrenario de rogación, que comenzó el día 15, implorando las misericordias del altísimo por la intercesión de su santísima madre bajo la advocación de sus dolores y [...] aún no había terminado la devota plegaria, cuando ya el cielo nos había socorrido con las aguas. ${ }^{50}$

\section{Las devociones protectoras}

Si bien en el mundo mesoamericano y andino en estas ocasiones generalmente se aludía a los Dioses en general, y en algunos casos a una deidad específica: Quetzalcóatl o Tezcatlipoca, Pachacamac o Pachamama, en el ámbito cristiano, y particularmente en el católico, las devociones protectoras resultan ser, en ocasiones, verdaderamente abundantes. Con la Reforma Protestante y el cuestionamiento a la dotrina de la Iglesia Católica, incluidos la veneración a la Virgen y a los santos, esa profusión desaparece en los credos resultantes de la escisión.

A los santos protectores, que en ocasiones devenían santos patronos, se les elegía en función de diversos elementos. Porque el desastre coincidía con su santoral, porque había sido ya invocado en situaciones similares, porque había

49. Fulton, 2012: 64-66.

50. Gazeta de México, en: García Acosta, Pérez y Molina, 2003: 384. 
mostrado su eficacia al invocarlo y disminuir o cesar la amenaza correspondiente, o bien porque salió triunfante en un sorteo o porque acudió a ofrecerse como tal. El siguiente ejemplo combina varios de los motivos esbozados. En 1671, a raíz del temblor que afectó seriamente San Salvador, «los regidores reunieron los documentos administrativos que describían la historia de la llegada de la Virgen de la Merced a esa ciudad», la cual databa de 1594, fecha en la que había ocurrido otro temblor muy destructivo; en esas fechas, y tras previas negociaciones, se había adoptado a esa advocación en sustitución de la Serenísima Virgen Reina de los Ángeles. Si bien la Virgen de la Merced, ya reconocida como «protectora, encargada de defender ante el cielo la causa de los habitantes [...] no impidió que el temblor de 1671 asolara a la ciudad», su poder fue evidente ya que « los sismos amainaron tan pronto la sacaron de la iglesia». ${ }^{51}$

Los casos en que la selección se derivaba de una auto-propuesta no son muy abundantes. El siguiente ejemplo conjuga esta modalidad con aquélla del sorteo. San Felipe de Jesús, criollo franciscano que murió martirizado en Japón en 1597 y que fuera santo patrono de la villa de Colima en el occidente de México. ${ }^{52}$ Resulta que estando reunido el ayuntamiento de esa villa para nombrar santo patrono contra los temblores, a raíz de los experimentados en 1609 ,

Un franciscano se acercó al portero de la casa consistorial, diciéndole que fuera con los regidores y les dijera que pusieran en las cédulas a San Felipe, santo patrono mexicano que fue franciscano, y si resultase electo les sería buen patrón [...] se verificó la rifa y por tres veces seguidas el triunfo fue de San Felipe de Jesús. Se buscó en vano al regidor que había hecho la sugerencia, y como no fuera ninguno de los residentes de la villa, se llegó a la conclusión de que el mismo santo vino a ofrecerse como patrón de la villa. ${ }^{53}$

Al evento como tal, también podía bautizárele con el nombre de alguna virgen o de algún santo, generalmente porque había coincidido el santoral. La devastación de Manila en 1645, en la cual más de 600 personas murieron, fue ampliamente conocida como el «temblor de San Andrés», dado que su

51. MUSSET, 1996: 61.

52. Raymundo Padilla ha estudiado este caso en detalle: PADILLA, 2014.

53. En García ACOSTA y SuÁrez ReYnOSO, 1996: 87. 
celebración es el 30 de noviembre. Por su parte, al que se presentó en esa misma ciudad la noche del 1 al 2 de noviembre de 1791, se le conoció como el «terremoto de la Candelaria», ${ }^{54}$ al haber coincidido con esta fiesta religiosa que conmemora la aparición de la Virgen de ese nombre en las islas Canarias en el siglo XV, festividad que se celebra aún en la actualidad en varios países de Hispanoamérica.

A algunos santos se les identificaba específicamente con cierta enfermedad, alguna de las cuales podía convertirse en epidémica. El jesuita alemán Juan de Esteyneffer (1664-1716), después de haber estado de misionero en el norte de lo que hoy es México, incluyó información al respecto en su manual de medicina titulado Florilegio Medicinal. Señala que: «San Marcial, San Francisco Javier y Santa Rosalía escuchan a quien sufre de sarampión o viruela [...] San Vicente no desecha las súplicas de quien tenga un hueso roto y [...] Santa Dorotea es, entre toda la jerarquía celeste, la que probablemente más intercederá en favor de quien se haya descoyuntado una rodilla.» ${ }^{55}$ Algunos casos, como el de las epidemias en Alsacia, que alcanzaron cerca de la docena entre 1439 y 1600, dejaron como resultado más de 60 altares, capillas e iglesias dedicadas a San Sebastián, el más célebre protector contra las epidemias en Francia. Sólo en los retablos de la diócesis de Mans entre los siglos XVII y XVIII, este santo ocupaba el tercer lugar como protector contra la peste, antecedido por la Virgen y los apóstoles Pedro y Pablo. ${ }^{56}$

A diferencia de ello, algunas devociones resultaban muy populares y estaban bien cotizadas, al grado que se les consideraba como protectoras ante la presencia no de una sola, sino de varias amenazas o desastres. Es el caso de la Virgen mexicana por antonomasia, la virgen morena, la Guadalupana, que se apareció en 1531. Incluso antes de haber sido designada oficialmente como Patrona General del Reino de la Nueva España por bula emitida en 1754 por el papa Benedicto IV, se le conmemoraba, trasladaba y veneraba en casos de inundaciones (1629), epidemias (1627, 1736), sequías (1741), temblores (1753). ${ }^{57}$ En dicha designación fue determinante su vigorosa intermediación

54. BANKOFF, 2003: 170.

55. COOPER, 1980: 55-56.

56. WALTER, 2008: 51-52.

57. Esta advocación mariana también resultó eficaz cuando los colimenses invocaron su protección en 1617, ante la invasión de corsarios ingleses a quienes, aun siendo más 
durante la que se puede considerar como la peor epidemia del siglo XVIII novohispano, la de matlazahuatl, a la que ya nos hemos referido en este ensayo. Su estudiosa nos narra que durante 1737 «se realizaron en tan sólo tres meses cerca de diecisiete actos religiosos entre novenarios, misas cantadas y plegarias. ${ }^{58}$ Durante el resto del periodo colonial novohispano y buena parte del siglo XIX, la Virgen de Guadalupe siguió teniendo un lugar prioritario en este tipo de celebraciones.

En casos de desastres convergentes, a una misma devoción protectora podía solicitársele, o reconocérsele, su intervención en sentido amplio. El temblor en Caracas de 1766 fue de poca intensidad y sorprendió a la ciudad presa de otros padecimientos. Sus habitantes estaban

en fervorosa adoración a las vírgenes para remediar el mal de las viruelas. Esto condujo a creer que los escasos efectos del sismo resultaban como milagro y protección de la virgen de La Merced, especialmente, y de la del Rosario, patrona de los temblores en la ciudad hasta entonces [...] Convencidos de que su presencia les salvó de la ruina generalizada, decidieron agradecerle por diferentes vías [...] Se hicieron fiestas, Te Deum, misas, y todo tipo de oraciones [...] el obispo, Antonio Diez Madroñero a la sazón, ordenó rogativas públicas en acción de gracias mediante tres procesiones, todas partiendo de la catedral. ${ }^{59}$

En contraste, algunos santos o vírgenes podían ser des-nombrados, abandonados o sustituidos por otros, generalmente cuando, a pesar de haberlos invocado y haberles dedicado todo tipo de rezos y ceremonias, no habían logrado que el desastre amainara. Es el caso de Santiago de Guatemala, cuando los terremotos de 1575 «indujeron a los habitantes a abandonar al santo Santiago y a encontrar otro patrono, San Sebastián, ya que los sismos se calmaron un 20 de enero, día consagrado a este mártir. ${ }^{60}$

La enorme variedad de devociones protectoras, fueran santos, advocaciones marianas, o el propio Jesucristo, se podía presentar en una misma región y

numerosos, fueron vencidos. En esta ocasión fue proclamada patrona y protectora, con lo cual «el patronato guadalupano colimense se convirtió en el primero en México»: PADILLA, 2014: 98.

58. MolinA, 2001a: 113. En la página 153 aparece detallada la procesión que, para pedir su apoyo e intervención, se celebró en el mes de mayo de 1737.

59. ALTEZ, 2016: 332.

60. MUSSET, 1996: 59.

Revista de Historia Moderna, n. ${ }^{\circ} 35$ (2017) (pp. 46-82) | ISSN-e: 1989-9823 | ISSN: 0212-5862 
relacionada con un mismo desastre. Es el caso que relata Alberola, vinculado con plaga de langosta en Valencia de 1756:

En la villa de Cocentaina se «procedió a designar por sorteo al patrón contra las plagas, recayendo este título en el Cristo de los labradores [...] la villa de Castalla sacó en solemne procesión al Cristo de la Sangre y a la Virgen de la Soledad; Vinaroz hizo lo propio con la Virgen de la Misericordia y Segorbe expuso en su iglesia parroquial la imagen de la Virgen de la Cueva Santa [...] Orihuela [...] paseó la imagen de Nuestro Padre Jesús Nazareno y [...] en Elda se había llegado a realizar hasta dos procesiones diarias portando la imagen de la Virgen [y en] Xátiva [... ] al denominado Cristo del Carmen. ${ }^{61}$

Una de las fuentes para el estudio de las devociones protectoras vinculadas con desastres, y particularmente con enfermedades, son los exvotos, retablos o tabletas votivas, que ilustran con claridad ese carácter milagroso adjudicado por la población a alguna advocación de la Virgen o a algún santo o santa por la curación de enfermedades, por haber salido ileso de un accidente, por no haber perecido ante la presencia de una amenaza natural o biológica. La información que ofrecen no es demasiado detallada ni sistemática, no obstante es de importancia particular dado que, como he mencionado ya, dichas pinturas narrativas constituyen verdaderas fotografías de la época. ${ }^{62}$

\section{Usos políticos de la concepción providencialista}

Estudiar a los desastres y sus diferentes manifestaciones como procesos, permite aprehenderlos en toda su complejidad, e identificar los elementos de variada índole que intervienen en ella. No es frecuente que los estudiosos de estos temas atiendan las vinculaciones políticas de dichas manifestaciones, que es lo que pretendemos ejemplificar en este apartado como los usos políticos de la concepción providencialista, en el caso de la ocurrencia de desastres asociados con amenazas de origen natural o biológico. Lo haremos a

61. Alberola, 2003: 400.

62. GARCíA ACOSTA, 2016: 63. A la par de los numerosos exvotos expuestos en la Iglesia de San Francisco (Real del Catorce, San Luis Potosí, México) y de Notre Dame de la Garde (Marsella, Francia), existen excelentes compilaciones para México; por mencionar un par de los mejores cfr. CENTRO CULTURAL ARTE CONTEMPORÁNEO, 1996 y CENTRO DE CULTURA CASA LAMM, 2010. Para temas específicos (migración, mujeres), los publicados por Jorge Durand y Patricia Arias. 
partir de revisar, por un lado, el papel que jugó el enfrentamiento de católicos y protestantes, tanto en el «viejo» como en el «nuevo» mundo y, por otro, un ejemplo específico ya en plena Ilustración: el que ofrecen las reflexiones relacionadas con los sismos venezolanos de marzo de 1812 .

\section{Católicos versus protestantes}

Quienes profesaban diferentes credos cristianos coincidían en reconocer como divino tanto el origen como el castigo en la ocurrencia de desastres. Una evidencia de ello aparece en la comparación que lleva a cabo Elaine Fulton entre tres sermones predicados por un escritor de almanaques luterano en 1578 (Matthaeus Bader), un poeta y clérigo anglicano en 1580 (Abraham Fleming) y un obispo católico de Viena en 1590 (Johann Neubeck), coincidiendo todos en que Dios es la causa primaria y la naturaleza sólo su instrumento y herramienta. ${ }^{63}$ Lo que hacía la diferencia entre ellos era el uso o los usos políticos que se le daba a estas concepciones en casos específicos.

A lo largo de los siglos XVI y XVII, el protestantismo en Europa se fue extendiendo de manera creciente. Los católicos, como lo habían hecho por siglos, reaccionaban ante las amenazas naturales y biológicas suplicando la intercesión divina, mayoritariamente a través de pedir la intervención a diferentes advocaciones marianas y a la enorme pléyade de santos. Los protestantes, por su parte, echaban mano de la defensa de su doctrina cuando los desastres se presentaban en regiones católicas, argumentando que les ocurrían por no tocar en la puerta correcta, no acudir al pozo adecuado y no buscar la ayuda en Dios mismo; ¿para qué pedir auxilio a los santos si son débiles e incapaces de ayudar?, ¿cómo van a ayudar si ya están muertos? ${ }^{64}$

Esta guerra, constante y persistente, entre protestantes y católicos se evidencia a partir de las acusaciones de aquéllos de adjudicar la ocurrencia de los desastres al castigo divino, por no reconocer la fe verdadera. Los efectos diferenciales de ciertos sismos sirvieron al autor del panfleto antipapista, John Shower antes citado, para insistir en que quienes no abrazaban la fe

63. FULTON, 2012: 55-56. Una espléndida pieza al respecto es The Doctrine of Earthquakes. Two Sermons preached at a particular fast in Veymouth, Nov. 3. 1727. The Friday after the Earthquake, del Pastor calvinista Thomas Paine.

64. Fulton, 2012: 69. 
verdadera eran castigados por el Todopoderoso, y ponía como ejemplo el que antes de la reforma protestante los desastres ocurrían de manera generalizada y no diferenciada, pero que después de la misma las regiones católicas eran las más afectadas. ${ }^{65}$

En las publicaciones inglesas sobre el temblor de Lima y Callao de 1746 , resulta evidente la insistencia sobre el estado de decadencia de la sociedad colonial católica, cuyos lujos y «modales afeminados» daban cuenta de la impiedad y la sexualidad desenfrenada. ${ }^{66}$ Algo similar ocurrió con el temblor de Lisboa de 1755, ocasión en que la comunidad extranjera más numerosa residente en esa ciudad, que era precisamente la inglesa, produjo una gran cantidad de documentación sobre el evento. Reconocíendo vivir muy felices en tierras lisboetas, los predicadores protestantes aprovecharon para, como se dice popularmente, «llevar agua a sus molinos» afirmando que la ira de Dios había caído sobre aquéllos que cometían pecados mayores en su práctica religiosa: la Inquisición con sus actos de fe, y las imágenes de los santos comparables a los ídolos que el propio Moisés había destruido. ${ }^{67}$

Afirmaban que ese terrible desastre de Lisboa incluyendo temblor, maremoto e incendio, había ocurrido por las faltas graves cometidas por los católicos, así como por no haber atendido las advertencias previas. El jansenista francés Laurent-Etienne Rondet publicó en 1756 Reflexións sur le Désastre de Lisbonne, a través de las cuales pretendía demostrar que la ira de Dios se puede manifestar en una serie de hechos que la provocan. Rondet justificaba la catástrofe a partir del grave pecado de Lisboa, capital de un país que acogió a los jesuitas. De acuerdo con su teoría, un sismo anterior, en 1531 fue el aviso divino que el papa Juan III no identificó. Al dejar entrar a la Compañía de Jesús en Portugal, legó a sus futuros habitantes dos calamidades: que España

\section{WALTER, 2008: 45}

66. WALKer, 1999 y WALter, 2008: 54. PÉREZ MallainA, 2001. Ver asimismo el dossier que el Anaurio de Estudios Americanos, coordinado por Pablo E. Pérez Mallaina, dedicó en 2005 a Las crisis en la Hispanoamérica colonial como instrumento de análisis histórico.

67. SOUSA, 1990: 14. El Prólogo de Maria Leonor Machado de Sousa antecede la magnífica edición de la hermosa y reveladora publicación de los testimonios de ingleses, que fueron testigos presenciales de ese memorable temblor; incluye una compilación de cartas, relatos y escritos de comerciantes, religiosos, diplomáticos, acompañados de una selección de extraordinarias imágenes de ilustradores de la época relacionadas con el evento. Ver asimismo QUENET, 2005. 
se anexara ese país, pues en 1580 el Reino de Portugal pasó a ser parte de la Monarquía Hispana, y que Lisboa fuera víctima del desastre de $1755 .{ }^{68}$ De manera que los portugueses perdieron por dos vías: la anexión de 1580 y el temblor de 1755: castigos divinos con casi dos siglos de diferencia...

En el caso del temblor del 6 de abril de 1580, sentido en Inglaterra tanto en Anglia Oriental como en Londres y Kent, las respuestas tanto de la población como de las autoridades dan cuenta de la «confesionalización del desastre», como titula Fulton su interesante ensayo. Los impactos provocados proveyeron no sólo una oportunidad para robustecer el sentimiento anti-católico, sino también para reforzar la identidad religiosa protestante a partir de la proclamación nacional del así denominado «Día de la Expiación» ( «Day of Atonement») el cual incluía, de manera similar a las procesiones y rogativas católicas, oraciones públicas, cantos de salmos y asistencia a los sermones y actos oficiados por los pastores. Esta respuesta no sólo reconfortaba a las víctimas de ese sismo, sino que tenía también como finalidad instaurar el orden, el control y una clara declaración de la continuidad e inquebrantabilidad del protestantismo de la Inglaterra Isabelina. ${ }^{69}$ Se trataba así de respuestas con un claro cariz político. ${ }^{70}$

Algo similar se presentó con el gran incendio que destruyó el centro de Londres en septiembre de 1666, en cuyo caso los holandeses consideraron que se trataba de un castigo para el país con el que estaban en guerra; los ingleses, por su parte, lo atribuyeron a un complot papista, mientras que los españoles, en revancha, enfatizaron que una capilla católica se había preservado como signo de la intención de la Providencia de castigar a los herejes protestantes. ${ }^{71}$

\section{Sismos e independencia}

Uno de los mejores ejemplos del uso político es el del conocido como «temblor de Caracas» de marzo de 1812, estudiado profusamente por Altez. En su última obra, el autor da cuenta de la construcción social de la vulnerabilidad en Venezuela a lo largo de cuatro siglos de su historia, a partir de revisar los

68. Basado en SOUSA, 1990: 10.

69. FULTON, 2012: 61-62.

70. JANKU, SCHENK Y MAUELSHAGEN, 2012: 8.

71. WALTER, 2008: 51 
temblores ocurridos. Si bien su interés no es precisamente el de describir las manifestaciones religiosas asociadas con cada uno de ellos, nos brinda excelentes descripciones al respecto, las cuales dan cuenta clara de la consideración providencialista de los fenómenos. Va llevando de la mano al lector para mostrar, en cada caso, cómo los desastres ocurridos fueron producto de una serie de condiciones que bien caracteriza como de vulnerabilidad, misma que asociada en particular con una pobreza endémica, se fue incrementando, modificando, ampliando al grado de ser la responsable directa de los impactos asociados con la presencia de temblores, en algunos casos vinculados con otras amenazas naturales y biológicas como sequías, pestes y epidemias.

Da ejemplos varios de la vinculación entre desastres, religiosidad y política. Como aquél de 1610, en el cual Joan de Aguilar, corregidor y justicia mayor de La Grita, utilizó el mismo argumento para describir el origen del temblor que para zanjar un asunto que sobre minas estaba candente, atribuyendo a Dios «la causa de todo» y aclarando que los vecinos de esa ciudad llevaban a cabo procesiones «dando gracias a Dios Nuestro Señor por las mercedes que les ha hecho, y porque con los temblores tan grandes se descubrió esta mina de cobre, y con el mismo temblor se hundió la ciudad ${ }^{\prime} .{ }^{72}$ Pero sin duda el ejemplo más claro es al que ha dedicado de manera obsesiva, como él mismo lo reconoce, profundas reflexiones y numerosas publicaciones: el del temblor del jueves santo 26 de marzo de 1812 y su vinculación con la independencia de Venezuela. ${ }^{73}$

El Acta de independencia se había declarado en julio de 1811 y con ella nació la Primera República, que se estaba desmoronando al presentarse el sismo que dejó a Caracas literalmente en el suelo. La lectura que al respecto hace Altez de esa coyuntura desastrosa que «implica separarse críticamente de la forma como los historiadores e historiógrafos han percibido los mismos hechos» ${ }^{74}$ permite, al escoger a los terremotos como «ventanas de observación» aproximarse «a la relación que esa sociedad produjo con la naturaleza que la rodeaba [...] como una articulación históricamente producida y reproducida en el tiempo [...] y no como la convergencia eventual y casual

72. ALtEZ, 2016: 135

73. Altez, 2006, 2010 y 2016.

74. Altez, 2006: 24.

Revista de Historia Moderna, n. ${ }^{\circ} 35$ (2017) (pp. 46-82) | ISSN-e: 1989-9823 | ISSN: 0212-5862 
de dos tipos de procesos diferentes, el histórico y el natural. ${ }^{75}$ Lo anterior lo lleva a hablar de la historia de la vulnerabilidad de Venezuela a lo largo de los siglos, dando cuenta, como hemos afirmado en otros momentos, que la presencia de determinadas amenazas naturales o biológicas y la ocurrencia de desastres, constituyen el detonador de condiciones críticas preexistentes.

Pero el uso político que se dio en su momento se reflejó de varias maneras. La carta pastoral de quien fuera por 25 años arzobispo de Caracas, Narciso Coll y Prat, atribuyendo el desastre a un castigo divino derivado de la declaración de independencia unos meses atrás, muestra de que en general el clero seguía siendo leal a la Monarquía. Su actitud le valió la expulsión por parte del tambaleante gobierno de la Primera República, fundamentada en argumentos como los siguientes:

«[la] Pastoral dirigida a todos los pueblos venezolanos, demostrándoles que dicho suceso no ha sido, sino un efecto tan común en el orden de la naturaleza, como el llover, granizar, centellear \&c. o que a lo más habrá servido de instrumento, como pueden ser los extremos de los demás, a la Justicia Divina para castigar los vicios morales, sin que tenga conexión alguna con los sistemas y reformas políticas de Venezuela.» ${ }^{76}$

Otro ejemplo surge de la rivalidad antigua entre Caracas y Valencia por ser capital de la República, que justificaba esta última utilizando también elementos que mezclaban el origen del temblor con la condición política y los efectos en Caracas: «El pueblo de Caracas acostumbrado a revoluciones, y que en su seno ha procreado inmensa juventud nutrida en principios tan detestables, no puede asegurarles (sin que transcurran) muchos años [...] que no volverá a sorprender y deponer las legítimas autoridades, para sustituirlas por otras revolucionarias»..$^{77} \mathrm{La}$ capital se quedó en Caracas, pero el orden monárquico retornó...

75. Altez, 2016: 455

76. Agradezco a Rogelio Altez haberme proporcionado esta referencia, que corresponde al texto enviado por Antonio Muñoz Tébar, Secretario interino de Estado, al Arzobispo de Caracas, el 4 de abril de 1812.

77. Altez, 2016: 437. 


\section{¿Efectos de la Ilustración?}

Si bien no se puede dejar de reconocer que durante la Ilustración ciertamente se desarrollaron ideas relacionadas con el progreso y la expansión científica, tecnológica, económica y política, el estudio histórico-social de los desastres en espacios y tiempos diversos, da cuenta de que las perspectivas científicas sobre la presencia de amenazas naturales y la ocurrencia de catástrofes puede remontarse, incluso, a la época clásica griega. Tomando el caso de los temblores en particular, su origen preocupó a Aristóteles. En sus Meteorológicos e influido por su maestro Platón, lanzó su propia teoría a partir de las anteriormente elaboradas por Pitágoras, Anaxímenes y Demócrito: «al interior de la tierra existe un fuego permanente que da lugar a un soplo o pneuma y a exhalaciones que, al desplazarse, provocan los temblores», explicación que se mantuvo por muchos siglos, enriquecida por Séneca en el siglo I a. C. agregando el papel central del aire que «encerrado en esas cavernas subterráneas, al calentarse y no encontrar salida provocaba los temblores.» La identificada como «tradición aristotélica-senequista» continuó siendo la dominante durante la Edad Media y el Renacimiento para, en el siglo XVII y a partir de las reflexiones del jesuita alemán Athanasius Kircher, sumar al viento el fuego, e identificarlos como los dos elementos determinantes en la ocurrencia de temblores. ${ }^{78}$ Esta tradición aristotélico-kircheriana sobre el origen natural de los temblores se mantuvo hasta los inicios del siglo Xx en todo el mundo occidental, hasta que Alfred Wegener lanzó su teoría sobre la tectónica de placas, que tardaría décadas en ser reconocida.

A lo largo del periodo comprendido en este ensayo, eran ésas las ideas científicas que, al menos en el caso de los temblores y los fenómenos a ellos asociados como las erupciones volcánicas, privaban. Pero a partir de la conquista de los territorios del «nuevo» mundo, hubieron de convivir e, incluso, subsumirse a los paradigmas dominantes relacionados con el origen divino y punitivo de ésas y otras manifestaciones de la naturaleza, en particular cuando se asociaban con la ocurrencia de desastres. Podrían constituir manifestaciones de la naturaleza, pero era únicamente Dios quien daba las órdenes para castigar con esas manifestaciones las culpas y los pecados cometidos.

78. GARCíA ACOSTA, 2014: 72-73. 
Considerando lo anterior, coincidimos con las afirmaciones de que esta compleja y complementaria relación entre explicaciones científicas y religiosas de las causas de los desastres es bastante anterior. El aceptar al Todopoderoso como la causa primera no excluía causas secundarias o terciarias, fueran éstas científicas e, incluso, sociales. ${ }^{79}$ De hecho, las explicaciones científicas sobre las causas de los temblores, las erupciones volcánicas, las epidemias, las plagas y los desastres en general, han convivido y competido con las religiosas a todo lo largo de la historia occidental, y en ocasiones ambas han sido usadas «en tándem», que es la oportuna expresión que usa Johns para definirlo. Sí, en tándem, pero lo interesante del siglo XVIII y de la Ilustración es que fue entonces cuando se inició un serio y bastante generalizado cuestionamiento a la idea del origen providencialista de los desastres.

La creciente laicización durante el siglo XIX, y sobre todo durante la segunda mitad del mismo, llevó a transitar de cambios de énfasis a cambios cualitativos de fondo. No obstante, siguieron conviviendo y aún conviven «en tándem», varias explicaciones sobre el origen de las amenazas naturales y de los desastres: el providencialista y el científico. Cada una ha aportado, en su momento, elementos importantes en aras de alcanzar la prevención. A ellas se ha sumado, apenas en las últimas décadas, aquélla que constituye la verdadera explicación de los mismos: el incremento de los riesgos y de las vulnerabilidades. Pero ésa es, ya, otra historia...

79. JANKU, SCHENK y MAUELSHAGEN, 2012: 8. JOHNS, 1999: xvii-xviii. 
Actuales países latinoamericanos incluidos en los ejemplos

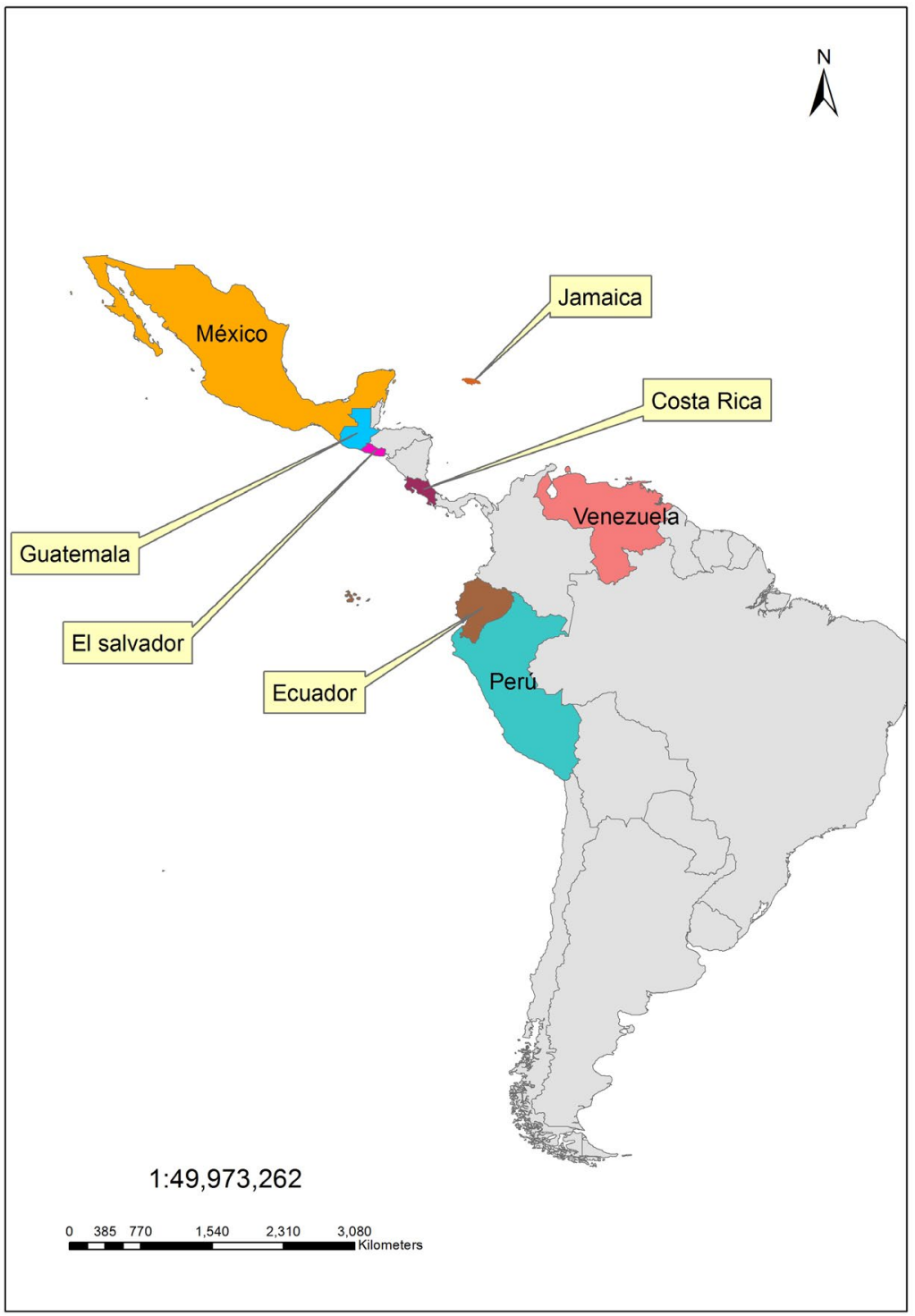

Elaboración de Anna Carolina Jiménez Reyes

Revista de Historia Moderna, n. ${ }^{\circ} 35$ (2017) (pp. 46-82) | ISSN-e: 1989-9823 | ISSN: 0212-5862 


\section{Actuales países de Eurasia incluidos en los ejemplos}

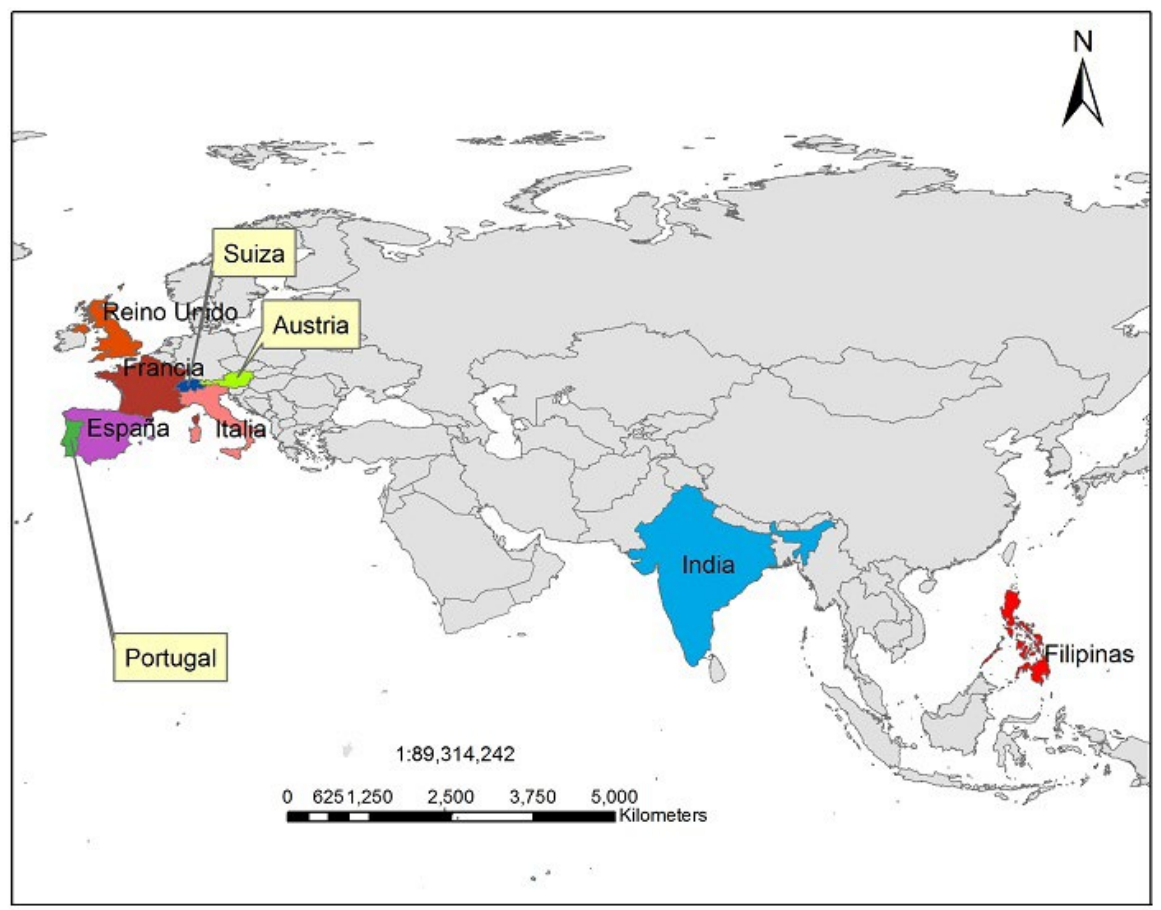

Elaboración de Anna Carolina Jiménez Reyes 
Actuales entidades federativas mexicanas incluidas en los ejemplos

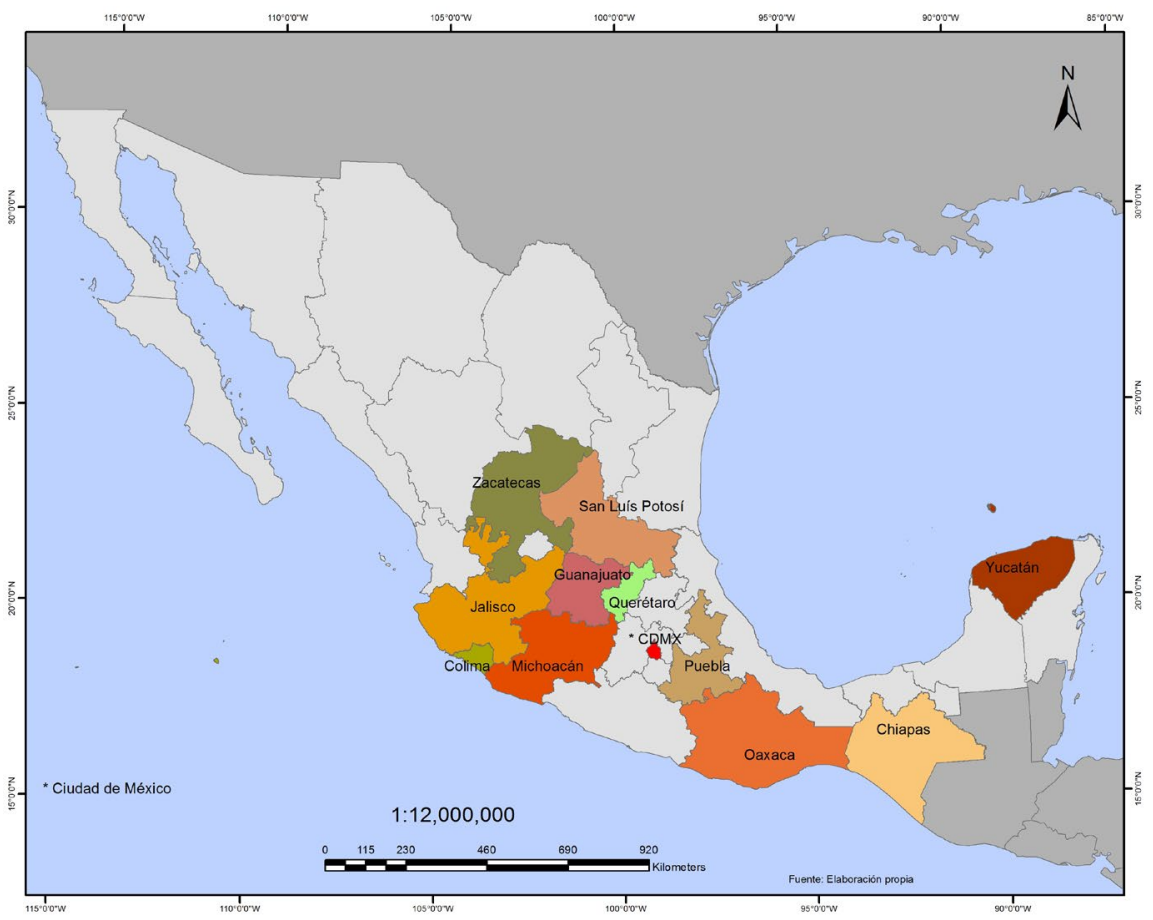

Elaboración de Anna Carolina Jiménez Reyes 


\section{Referencias bibliográficas}

Alberola Romá, Armando: «Clima, desastre y religiosidad en los dietaristas valencianos de los siglos XVI y XVII, Obradoiro de Historia Moderna, 25 (2016): 41-66. http://dx.doi.org/10.15304/ohm.25.3279

Alberola RomÁ, Armando, «El terremoto de Lisboa en el contexto del catastrofismo natural en la España de la primera mitad del siglo XVIII», Cuadernos Dieciochistas, 6 (2005): 19-42. Disponible en: http://revistas.usal.es/index. php/1576-7914/article/view/3751

Alberola RomÁ, Armando, «Procesiones, rogativas, conjuros y exorcismos: el campo valenciano ante la plaga de langosta de 1756», Revista de Historia Moderna. Anales de la Universidad de Alicante, 1 (2003): 383-410. http:// dx.doi.org/10.14198/RHM2003.21.17

Alberola RomÁ, Armando, «Temps de sequera, rogatives i avalots al sud del País Valencià (1760-1770)», Estudis d'Historia Agraria, 2004: 35-48. Disponible en: http://www.raco.cat/index.php/EHA/article/view/99939

Alberola RomÁ, A., Bueno Vergara, E. y García Torres, A., «Sequía y rogativas en tierras meridionales valencianas durante el siglo XVIII», en Luis A. Arrioja y Armando Alberola, (eds.): Clima, desastres y convulsiones sociales en España e Hispanoamérica, siglos XVII-XX, Zamora/Alicante, El Colegio de Michoacán/ Publicacions de la Universitat d'Alacant, 2016: 123-155.

Albores, Beatriz y Johanna BRODA (coords.), Graniceros. Cosmovisión y meteorología indígenas en Mesoamérica, México, El Colegio Mexiquense/ Universidad Nacional Autónoma de México, 2. ${ }^{a}$ ed., 2003.

Aldana Rivera, Susana, « ¿Ocurrencias del tiempo? Fenómenos naturales y sociedad en el Perú colonial», en Virginia García Acosta (coord.), Historia y Desastres en América Latina, vol. 1, Bogotá, LA RED y CIESAS, 1996: 123145. Disponible en: http://www.desenredando.org/public/libros/1996/hydvl/ HistoriaYDesastresVol_I-1.0.0.pdf

AlteZ, Rogelio, El desastre de 1812 en Venezuela: sismos, vulnerabilidades y una patria no tan boba, Caracas, Universidad Católica Andrés Bello/Fundación Polar, 2006.

AltEZ, Rogelio, «New interpretations of the social and material impacts of the 1812 earthquake in Caracas, Venezuela», en Manuel Sintubin et al., (eds.), Ancient Earthquakes, Boulder, Geological Society of America, Special Paper 471, 2010: 47-58. Disponible en: http://sociedadyriesgo.red/wp-content/ uploads/publications/altez/New_interpretations_of_the_social_and_ma.pdf 
AltEZ, Rogelio, Historia de la vulnerabilidad en Venezuela: siglos XVI-XIX, Madrid, CISC/ Universidad de Sevilla/Diputación de Sevilla, 2016.

Anales de Cuauhtitlán. Noticias históricas de México y sus contornos, compiladas por D. José Fernando Ramírez y traducidas por los señores Faustino Galicia Chimalpopoca, Gumersindo Mendoza y Felipe Sánchez Solís, México, Anales del Museo Nacional, 1885.

Araújo, Ana Cristina, A morte em Lisboa: attitudes e representaçoes, 1700-1830. Lisboa, Ed. Noticias, 1995.

AraúJo, Ana Cristina, O terramoto de Lisboa. Lisboa e a Europa, Lisboa, CTT Correios, 2005.

ARNOLD, David, «Hunger in the Garden of Plenty: The Bengal Famine of 1770», en Alessa Johns (ed.), Dreadful Visitations. Confronting Natural Catastrophe in the Age of Enlightenment, Londres y Nueva York, Routledge, 1999: 81-112. Anuario de Estudios Americanos, 62/2 (2005), «Las crisis en la Hispanoamérica colonial como instrumento de análisis histórico» (Pablo E. Pérez Mallaína, coord.). Disponible en: http://estudiosamericanos.revistas.csic.es/index.php/ estudiosamericanos/issue/view/4

BÁez-Jorge, Félix, Rivera Balderas, Amado y Arrieta Fernández, Pedro, Cuando ardió el cielo y se quemó la tierra. Condiciones socioeconómicas y sanitarias de los pueblos zoques afectados por la erupción del volcán Chichonal, México, Instituto Nacional Indigenista, 1985.

BANKOFF, Greg, Cultures of Disaster. Society and natural hazards in the Philippines, Londres/ Nueva York, Routledge, 2003.

CAMINO DiEZ CANSECO, Lupe, «Una aproximación a la concepción andina de los desastres a través de la Crónica de Guamán Poma, siglo XVII», en Virginia García Acosta (coord.), Historia y Desastres en América Latina, vol. 1, Bogotá, LA RED y CIESAS, 1996: 101:122. Disponible en: http://www.desenredando. org/public/libros/1996/hydv1/HistoriaYDesastresVol_I-1.0.0.pdf

Campos Goenaga, María Isabel, «Cuando estaban enojados los dioses. El huracán de 1561: vulnerabilidad ideológica y prevención en la sociedad maya yucateca», en Virginia García Acosta (coord.), Historia y desastres en América Latina, vol. 3, México, LA RED/CIESAS, 2008: 165-186. Disponible en: http://www.desenredando.org/public/libros/2008/hyd/Historia_y_Desastres_ VolumenIII.pdf

Centro Cultural/Arte Contemporáneo, Dones y promesas. 500 años de arte ofrenda (exvotos mexicanos), México, Centro Cultural/Arte Contemporáneo, 1996. 
Cooper, Donald B., Las epidemias en la Ciudad de México. 1761-1813, México, Instituto Mexicano del Seguro Social, 1980.

Douglas, Mary, Risk and blame. Essays in cultural theory, Nueva York, Routledge, 1992.

FulTON, Elaine, «Acts of God. The Confessionalization of Disaster in Reformation Europe», en Andrea Janku, Gerrit J. Schenk y Franz Mauelshagen (eds.), Historical Disasters in Context. Science, Religion, and Politics, Londres/ Nueva York, Routledge, 2012: 54-74.

GARCía AcOSTA, Virginia, Los sismos en la historia de México, Tomo II: El análisis social, México, Fondo de Cultura Económica/UNAM/CIESAS, 2001.

GARCíA AcOSTA, Virginia, «Desastres históricos y secuelas fecundas», discurso de ingreso a la Academia Mexicana de la Historia, Memorias de la Academia Mexicana de la Historia. Correspondiente de la Real de Madrid, LV (2014): 65-91.

GARCÍA ACOSTA, Virginia, «La prensa novohispana y sus aportes para el estudio histórico-social de los desastres en México», en Luis A. Arrioja y Armando Alberola (eds.), Clima, desastres y convulsiones sociales en España e Hispanoamérica, siglos XVII-XX, Zamora/Alicante, El Colegio de Michoacán/ Universidad de Alicante, 2016: 61-80.

GARCíA ACOSTA, Virginia y SuÁrez REYNOSO, Gerardo, Los sismos en la historia de México, Tomo I, México, Fondo de Cultura Económica/UNAM, 1996.

García Acosta, Virginia, PÉrez Zevallos, Juan Manuel y Molina del Villar, América, Desastres agrícolas en México. Catálogo histórico, Tomo I: Épocas prehispánica y colonial (958-1822), México, Fondo de Cultura Económica/ CIESAS, 2003.

GARCÍA TORRES, Adrián, «Redención y luchas de poder a la hora de aplacar el brazo de la divina justicia: el caso de las rogativas en el Elche del s. XVIII», Revista de Historia Moderna. Anales de la Universidad de Alicante, 31 (2013): 109-125. http://dx.doi.org/10.14198/RHM2013.31.06

GARCÍA TORRES, Adrián, «Extremismo climático y desastre: fuentes documentales para el estudio de España y México en el siglo XVIII», Conferencia, Red Temática de Estudios interdisciplinarios sobre vulnerabilidad, construcción social del riesgo y amenazas naturales y biológicas, México, CONACYT y Coordinación Nacional de Antropología e Historia del INAH, 18 de octubre de 2016. (cfr. http://sociedadyriesgo.red/eventos/). Disponible en formato audiovisual en: https://youtu.be/oEqQTdAyHn8 
GieseCKe, Alberto y Silgado, Enrique, Terremotos en el Perú, Lima, Ediciones Rikchay, 1981.

JANkU, Andrea, SChenk, Gerrit J. y MaUelShagen, Franz, «Introduction» en Andrea Janku, Andrea, Gerrit J. Schenk y Franz Mauelshagen (eds.), Historical Disasters in Context. Science, Religion, and Politics, Londres/Nueva York, Routledge, 2012: 1-14.

Johns, Alessa, «Introduction», en Alessa Johns (ed.), Dreadful Visitations. Confronting Natural Catastrophe in the Age of Enlightenment, Londres/Nueva York, Routledge, 1999: XI-XXV.

JuÁrez BeCERril, Alicia María, Observar, pronosticar y controlar el tiempo. Apuntes sobre los especialistas meteorológicos en el Altiplano Central, México, Universidad Nacional Autónoma de México, 2015.

Kendrick, Th. D.: The Lisbon earthquake, Philadelphia/New York, J.B. Lippincott Company, 1955. Disponible en: https://archive.org/details/ lisbonearthquake010555mbp

KirChHOFF, Paul, «Mesoamérica. Sus límites geográficos, composición étnica y caracteres culturales», Suplemento de la revista Tlatoani, 3 (1967). Disponible una versión digitalizada en: http://www.posgrado.unam.mx/mesoamericanos/ uploads/docs/Paul\%20Kirchhoff.PDF

LÓPEZ AUSTiN, Alfredo, «La cosmovisión mesoamericana», en Sonia Lombardo y Enrique Nalda (coords.), Temas mesoamericanos, México, Instituto Nacional de Antropología e Historia, 1996: 471-507. Disponible en: https://es.scribd. com/doc/46476230/Lopez-Austin-La-cosmovision-mesoamericana

LÓPEZ Austin, Alfredo y LóPEZ LujÁN, Leonardo, «State Ritual and Religion in the Sacred Precinct of Tenochtitlan», en Deborah L. Nichols y Enrique Rodríguez-Alegría (eds.), The Oxford Handbook of the Aztecs, Oxford Handbooks Online Oxford University Press, Oxford, 2017. http://dx.doi. org/10.1093/oxfordhb/9780199341962.013.25

LUQUE AGRAZ, Elin et al., Los relatos pintados, la otra historia. Exvotos mexicanos, México, Centro de Cultura Casa Lamm, 2010.

Martins, Karla P. H., (org.), Profetas da chuva, Ceará, Tempo d’Imagem/ Universidad de Fortaleza, 2006.

Molina del Villar, América, Por voluntad divina: escasez, epidemias y otras calamidades en la Ciudad de México, 1700-1762, México, CIESAS, 1996.

Molina Del Villar, América, La Nueva España y el matlazahuatl. 1736-1739, México, CIESAS/El Colegio de Michoacán, 2001a. 
Molina Del Villar, América, «El sismo del 19 de junio de 1858», en Virginia García Acosta, Los sismos en la historia de México, Tomo II: El análisis social, México, Fondo de Cultura Económica, UNAM y CIESAS, 2001b: 221-263.

MUSSET, Alain, «Mudarse o desaparecer (siglos XVI-XVIII)», en Virginia García Acosta (coord.), Historia y Desastres en América Latina, vol. 1, Bogotá, LA RED/ CIESAS, 1996: 41-70.

Musset, Alain, Ciudades nómadas del Nuevo Mundo, México, México, Fondo de Cultura Económica, 2011.

OnetTo, Mauricio, Temblores de tierra en el jardín del Edén. Desastre, memoria e identidad. Chile, ss. XVI-XVIII, Santiago de Chile, DIBAM, 2017.

PAdilla LozoyA, Raymundo, «Representaciones en san Felipe de Jesús (santo patrono contra incendios y temblores)», en Aidée Arellano Ceballos y Carlos Ramírez Vuelvas (coords.), Imaginarios y representaciones sociales y culturales en transición, México, Universidad de Colima/ Editorial Praxis, 2014: 96-129. Disponible en: http://www.academia.edu/15521670/Representaciones_en_ san_Felipe_de_Jes\%C3\%BAs_santo_patrono_contra_incendios_y_temblores_en_Colima_M\%C3\%A9xico_Representations_in_San_Felipe_de_Jesus_ patron_saint_against_fires_and_earthquakes_in_Colima_Mexico

Peraldo Huertas, Giovanni y Mora FERnÁndez, Mauricio, «Enseñanzas de la actividad histórica de los volcanes Irazú y Turrialba», en Virginia García Acosta (coord.), Historia y desastres en América Latina, vol. 3, México, LA RED/CIESAS, 2008: 115-162.

PÉRez MallaínA, Pablo Emilio, Retrato de una ciudad en crisis. La sociedad limeña ante el movimiento sísmico de 1746. Sevilla, CSIC/Pontificia Universidad Católica del Perú, 2001.

QUENET, Grégory, Les tremblements de terre aux XVIIe et XVIIIe siècles. La naissance d'un risque, Seyssel, Champ Vallon, 2005.

SOUSA, Maria Leonor Machado de, «Prefácio. Preface», en Maria Leonor Machado de Souza (pref.) y Judite Nozes (intr.., trad. y not.), O Terramoto de 1755. Testemunhos Britânicos. The Lisbon Earthquake of 1755. British accounts, Lisboa, The British Historical Society of Portugal/Lisóptima Edições, 1990: 6-17.

SOUSA MOREIRA, V.: Contribução para o conhecimento de sismicidade historica de Portugal continental, Lisboa, Instituto Meteorológico Geofísico, 1984.

TOBRINER, Stephen, «Safety and Reconstruction of Noto after the Sicilian Earthquake of 1693-The Eighteenth-Century Context», en Alessa Johns 
(ed.), Dreadful Visitations. Confronting Natural Catastrophe in the Age of Enlightenment, Londres/Nueva York, Routledge, 1999: 49-77.

WALKER, Charles F., «Shaking the Unstable Empire: The Lima, Quito, and Arequipa Earthquakes, 1746, 1783, and 1797», en Alessa Johns (ed.), Dreadful Visitations. Confronting Natural Catastrophe in the Age of Enlightenment, Londres/Nueva York, Routledge, 1999: 113-144.

WALTER, François, Catastrophes. Une histoire culturelle. XVIe- XVIIe siècle, Paris, Éditions du Seuil, 2008. 